\title{
Toward an Urban Policy Analysis: Incorporating Participation, Multilevel Governance, and "Seeing Like a City"
}

Journal Article

Author(s):

Kaufmann, David (1); Sidney, Mara

Publication date:

2020-01

Permanent link:

https://doi.org/10.3929/ethz-b-000401394

Rights / license:

$\underline{\text { In Copyright - Non-Commercial Use Permitted }}$

Originally published in:

PS: Political Science \& Politics 53(S 1), https://doi.org/10.1017/s1049096519001380 


\title{
Politics Symposium
}

\author{
Toward an Urban Policy Analysis
}

\section{“Toward an Urban Policy Analysis: Incorporating Participation, Multilevel Governance, and 'Seeing Like a City"' \\ David Kaufmann, ETH Zürich \& University of Bern}

Mara Sidney, Rutgers University-Newark

Cities are active policy innovators of global importance, whether responding to climate change, migration, poverty, or addiction; whether aiming to generate growth or to reduce its negative impacts. Yet, cities also adapt to and comply with the needs and interests of global capital, implementing policies that slight the well-being of everyday residents and especially the most vulnerable. Indeed, these characterizations are not mutually exclusive, given the complexity and multiplicity of state actions. Assessed by their prospects for contributing to a just, democratic, and sustainable future, the set of policies that cities enact often may be found deeply ambivalent (Enright and Rossi 2017). This symposium suggests that to understand contemporary societal transformation — and political and policy processes more generally—-the policies that cities create and implement are essential objects of study. That is, an urban-policy analysis is not relevant simply because of the high volume of policy activity happening in cities but also because it highlights dimensions of political life that are more visible within cities but that also operate at other scales. Contemporary confrontations between public and private property, power and justice, participation and exclusion, wealth and poverty, and emerging technology and existing economic, social, and political structures take physical form in cities (e.g., Kaufmann 2019; Kohn 2016). Despite this importance of cities, a specifically urban policy analysis has not emerged. 
Stone $(2015,117)$ reminded us that "cities are not the nation-state writ small." Thus, urban political processes and the policies that emerge are likely to differ from processes and policies at other scales - international, national, or subnational. Yet, the dominant policy theories and concepts mostly stem from analyses of national political processes (e.g., Advocacy Coalition Framework and Multiple Streams) and may not be automatically applicable to cities. These theories do not explicitly consider scale and they do not include dimensions of politics identified as key in the urban-politics literature. Nonetheless, urban scholars have applied these theories, often integrating dimensions of local politics into their analysis (e.g., Sapotichne and Jones 2012; Trounstine 2009). This symposium instead aims to consider how a ground-up urban policy analysis can be built. That is, we argue for urbanizing the study of public policies and "seeing like a city" by detaching public-policy and political science studies from their nation-state focus and by developing theoretical foundations for urban-policy research built from urban empirical work (Enright 2019; Magnusson 2011, 2014).

This introduction describes three dimensions that emerge from empirical work presented in this symposium that may be suitable as building blocks of an urban policy analysis. First, urban policy analysis grapples with participation in the policy process. The density of the urban political arena and the immediacy of policy problems can result in a diverse set of actors from the public, private, and nonprofit or community sectors that aim to influence problem solving.

Coalitions — whether they are present, who takes part, and how long they last—are integral to much urban-politics literature. This symposium suggests that we also should consider how institutions hinder or encourage participation. Second, an urban policy analysis examines and can theoretically advance our understanding of the multilevel nature of governance. Government actors, social movements, institutions, and laws exert influence and strategically intertwine among and across levels of local, national, and supranational government. Third, an urban policy analysis 
would explicitly theorize "the urban." That is, scholars increasingly argue that "the urban" is a political arena that transcends geography, speaking rather to a mode of politics and daily life that is characterized by diversity, complexity, chaos, flexibility, and ongoing change. This type of urban lens on policy is attentive to contextual dimensions of the policy process not always recognized in general policy studies.

\section{ARTICLES IN THE SYMPOSIUM}

The authors in this symposium explore these three proposed key dimensions of urban policy making. The contributions include cases in which cities actively make policies in the absence of, complementary to, or opposed against policies at other governmental levels, such as migration (Bazurli 2019; Williamson 2019) and digitization (Bramwell 2019). They analyze more conventional urban-policy fields such as housing (Donaghy 2019) and large-scale infrastructure development (Hinze and Smith 2019), with fresh insights about the contemporary moment. The contributions offer analyses of a range of geographic sites and city types, including large and midsized cities in North America, Europe, and Latin America. This symposium concludes with an article provoking us to "see like a city" such that research would challenge the entrenched statism of political concepts and theories to account for a wider variety of urban experiences and political processes (Enright 2019).

The contributions draw on insights from urban studies, urban politics, and public policy and apply them to original empirical work. These subfields share an awareness of complexity and a related openness to interdisciplinarity that could lead to more explicit dialogue. It seems that an urban policy analysis is an interdisciplinary endeavor. The problems that policy seeks to address, and the urban environments that scholars seek to understand, emerge from complex webs of factors that often can be understood only through interdisciplinary inquiry. 


\section{DIVERSE ACTORS AND THE ROLE OF INSTITUTIONS IN PARTICIPATION}

This symposium demonstrates that close examination of participation is critical for an urban policy analysis. The contributions suggest that a diverse set of actors engage in processes at multiple levels of government while seeking to influence public policy. They analyze the changing roles of business, quasi-public authorities, and nongovernmental actors in coalition or in opposition as they interact with officials differently placed within government agencies and levels. The contributions also highlight the importance of institutions in shaping the participation process through their decision rules and the fragmentation of decision arenas.

First is the question of who participates. The role of business is well established in theories of urban politics (Molotch 1976; Stone 1989), and these articles address how and to what effect business takes part in urban-policy processes. They also reveal—in line with research on the postindustrial city - that stable business-government coalitions are no longer found (Stone 2015) because business is either involved in the short term only (Hinze and Smith 2019) or is, in fact, not involved at all (Bramwell 2019). For example, Bramwell (2019) compares local coalitions formed to address adaptation to the digital economy. Ironically for an economic-development policy area, she finds that the private sector is least involved in coalitions compared to government and foundations, universities, and other nonprofit organizations. Hinze and Smith (2019), conversely, find that the business sector closely coordinated with local government to sideline neighborhood opposition in large-scale redevelopment projects. Third-sector actors have emerged as key participants - even leaders — of coalitions. Bazurli (2019) and Williamson (2019) discuss the roles of social movements and nongovernmental organizations; Donaghy (2019) and Hinze and Smith (2019) consider access of neighborhood groups to decision making. However, like the business sector, third-sector actors encompass a range of organizations with varying levels of resources such that detailed analysis of which types of NGOs, foundations, and community organizations are able 
to participate, to sustain participation, and to have influence are important questions to examine (Clarke 2017). There also seems to be a need to include diverse modes of political participation, including informal activities as well as small-scale and intermittent interactions and conversations not always considered to be "political” (Landau 2014; Beveridge and Koch 2019; Wong 2019). Our takeaway from this symposium is that flux in participation over time and differences in participation across policy sectors emerge as the "new normal" in urban-policy processes as well as variation in outcomes across cities. Furthermore, conventional categories of participants are less helpful than a close examination of the diversity within public, private, and community or nonprofit sectors.

Several authors address the decisive role that institutions play in structuring participation. This means that attention to the creation and transformation of institutions is as important to urban policy analysis as attention to the policies themselves. For example, the creation of participatory governance institutions to determine and implement housing policy in São Paulo ensured over a long period that advocates for vulnerable populations shaped the allocation of housing resources (Donaghy 2019). By contrast, institutional designers may aim to prevent broad participation. Hinze and Smith (2019) show how institutional rules and practices repelled neighborhood resistance to large commercial and infrastructure developments in Chicago and Berlin. The creation of special authorities to guide development successfully sidelined neighborhood resistance and secured policies reflecting business interests (see also Lay and Bauman 2017; Sbragia 1996).

\section{ALL POLICY MAKING IS MULTILEVEL}

We suggest that a second fundamental dimension of an urban policy analysis is multilevel governance. Multilevel governance speaks to both the participants in decision making and implementation and the scales at which it occurs. It theorizes decision making by networks of government and nonstate actors operating across multiple scales without a single structuring 
authority (Hooghe and Marks 2003). Governance and the political processes leading to and constituting governance are complex because they occur through relationships that cross and intertwine jurisdictions, whether "discrete or nested territorial levels" and through "overlapping networks" of state and nonstate actors (Bache and Flinders 2004, 197). Multilevel governance has become relevant in urban politics to better account for complex institutional entanglements in which cities are embedded, as well as for political actions of urban actors beyond city boundaries (Kübler and Pagano 2012).

Several contributions show that urban policy making emerges from interactions between state and nonstate actors operating at multiple scales. Actors often do not stay within their "home" jurisdictions, but they can strategically engage in cross-level policy networks. Thus, policies issued at the urban scale are likely to be the product of interactions, deliberations, advocacy, and compromises among actors from multiple scales and spaces, both state and nonstate. For example, Bazurli (2019) shows how mayors and local social movements jointly engage in policy conversations with state and national agencies about immigration-policy problems. These social movements try to navigate around institutional policy-making constraints by exploiting venue-shopping opportunities. By contrast, Williamson (2019) finds a more hierarchical relationship between the national and local levels in US immigration policy. She isolates which federal immigration policies are most present in cities and shows that local officials craft different types of local immigration policies if they experience welcoming or punitive national policy. Bramwell (2019) explores both the opportunities for multilevel politics and the constraints of hierarchy. She examines whether sector-specific policy silos, levels of government, and state and societal divides can be bridged in the case of "ordinary cities" trying to cope with the disruptive potential of digital economic transformations. The capacity for urban policy making is shaped by the multilevel governance context in which individual cities are 
embedded and the resources that cities secure from higher-tier governmental levels.

Although findings in particular empirical cases vary, we suggest that a relational and multilevel dimension of analysis is critical for bringing to light actions across scales and possible connections among them. Without such a scan beyond the limits of city jurisdictions and formal local-autonomy constraints, researchers risk missing a key aspect of urban policy making. Such an analysis also builds on a strong tradition of research in urban politics that examines the material and political impacts of national urban policies in cities and, more recently, the impacts of sectoral policies including transit, welfare, and immigration (e.g., Sidney 2003, forthcoming). Indeed, public-policy theories of policy feedback and agenda setting are relevant here as well (Michener 2018; Williamson 2018). However, the multilevel-governance lens is more multidirectional in theorizing policy-making influences, and it encourages examining the incorporation of diverse actors (which resonates with our first proposed dimension).

\section{URBANIZING POLICY STUDIES}

A third promising dimension of an urban policy analysis is a deep analysis of the urban context, which includes interrogating the concept of "urban" as a regular practice when undertaking empirical research. Urban scholars have long theorized about what makes cities distinctive from other types of places (e.g., Davies and Imbroscio 2009; Dreier, Mollenkopf, and Swanstrom 2001; Trounstine 2009). This call goes further by incorporating the work of scholars who have developed a conceptual definition of "the urban" that identifies characteristics and processes that occur irrespective of geography and that may operate outside of the state (e.g., Magnusson 2011; Simone 2004). This analysis would consider the contextual characteristics of the urban that differ from those of the nation-state and also how inquiry could be decentered from the state.

Regarding the specific contextual characteristics of the urban setting, urban theories point to dimensions of size, density, and diversity of urban spaces as contributing to the particular visibility 
or immediacy of social, economic, and infrastructural problems in cities, even though these problems usually reflect broader forces originating beyond the city. This explains why cities might address policy issues prior to or with more urgency than national governments. Moreover, the urban lens attunes us to characteristics of politics that are actually ubiquitous but most apparent in cities. These include the complexity of policy making with interdependencies within and across boundaries, its constant flux, and its multiple sources of authority both within and outside of government. Overall, we could say that cities are burning glasses of our society that show societal and technological transformations most clearly in their speed, intensity, and relentlessness; they reveal everyday conflicts over exchange and use value and the diversity of actors and groups that try to exert authority in policy making. An analysis of cities, therefore, is relevant for more broadly understanding processes in society at large.

Scholars have distinguished usefully between the concepts of "local" and "urban." A "local" ontology views local policies as generated and implemented by local governments through local political processes, which distinguish them from policies that originate at higher levels of government. In this perspective, cities are mainly treated as the lowest administrative level. Scholars who conceptualize "the urban" argue for "seeing like a city." Such a perspective challenges a nation-centric analysis, offering an urban one in its place; "urban" is understood not as a geography but rather as a context irrespective of borders - and even as a normative stance. "The urban" is seen as a specific political arena, as "a local phenomenon and a global way of life" (Magnusson 2014, 1561). "The urban" is not a location but rather a condition in which many contemporary societal issues are problematized and performed (Boudreau 2016).

We believe that it can be fruitful for urban-policy scholars to engage with this body of work and that this, among our three components of urban policy analysis, is the least developed in empirical work to date — at least by political scientists. Enright addresses such a perspective most 
explicitly. Her call for the urbanization of policy studies rests on the implications of a set of contextual characteristics: "to see like a city" means to challenge the entrenched statism of political science and not to "replace one type of polity (the state) with another (the city)" (Enright 2019). She sketches attributes of an urban political ontology that "requires plural and relational tools of analysis and theory that can account for a variety of grounded experiences as well as common panurban conditions of possibility" (Enright 2019). Such a perspective seems to be a difficult conceptual shift for political scientists because we centrally examine state activities and everything around them. However, we find it stimulating for this symposium as well as for the discipline of urban politics more generally because it enlarges the range of relevant political actors (related to the first proposed dimension); it challenges formal policy-making hierarchies (related to the second proposed dimension); and it opens up new urban venues because the urban condition can be found outside of the city and may even be of planetary scope (Brenner and Schmid 2015).

\section{TOWARD AN URBAN POLICY ANALYSIS}

We propose that an intentionally developed urban policy analysis would include at least three elements: participation, multilevel governance, and "seeing like a city." As previously discussed, these elements are interrelated. Participation of a diverse set of actors is an essential element of both the multilevel-governance concept and the "seeing like a city" perspective.

Examining participation of a diverse set of actors based on diverse modes of political participation and analyzing multilevel-governance arrangements take us beyond formal authority, and both challenge nation-state centrism — both of which are core elements of "seeing like a city." Thus, bringing these concepts together into a single analysis seems possible, even if the core bodies of work from which they arise are disparate. It also can contribute to theory development because bringing together disparate lenses on urban policy also brings tensions to the surface within each type of approach. For example, there are interesting tensions related to the question of 
scale. "Seeing like a city" cautions against normalizing the nation-state; however, scholars working in this vein describe "the urban" not as a scale but rather as a set of conditions, possibilities, and characteristics. Multilevel governance centrally and straightforwardly incorporates scale into analysis. Yet, some early discussions of multilevel governance posed it as an integrative approach that broke from traditional political science subfields delineated by scale (i.e., national, state, and local) (Bache and Flinders 2004).

We approached this project centered on urban policy with questions about the meaning and distinctiveness of "the urban." Like Davies and Imbroscio's work on urban theory (2009), we asked whether urban policy analysis would entail taking general policy theories and adapting them to the urban scale. The work in this symposium strengthens our belief that the urban is a distinctive political arena that must be analyzed with interdisciplinary concepts that specifically theorize "the urban." Given the number of people living in cities and that processes of urbanization spill over city boundaries, there is a need not only for the urban research community to develop specific theories but also for the different social science communities to urbanize their disciplines. This symposium should be a contribution to both endeavors: we aim for theoretical and conceptual advancements to have tools in hand that allow us to analyze urban policies, and we want to contribute to an urbanization of political science and public policy that relaxes the implicit or explicit focus on the nation-state and its institutions. 


\section{ACKNOWLEDGMENTS}

The authors thank Susan E. Clarke for her thoughtful comments on these articles. The final product benefited greatly from her insights. This symposium developed from a workshop of the

International Public Policy Association held in June 2018. We thank all of the workshop participants for contributing to its insightful discussions. 


\section{REFERENCES}

Bache, Ian, and Matthew Flinders (eds.). 2004. Multi-Level Governance. Oxford: Oxford University Press.

Bazurli, Raffaele. 2019. “How ‘Urban’ Is Urban Policy Making?” PS: Political Science \& Politics (this issue).

Beveridge, Ross, and Philippe Koch. 2019. "Urban Everyday Politics: Politicising Practices and the Transformation of the Here and Now." Environment and Planning D: Society and Space 37(1): 142-157.

Boudreau, Julie-Anne. 2016. Global Urban Politics: Informalization of the State. Malden, MA: Polity Press.

Bramwell, Allison. 2019. “Innovation and the 'Ordinary’ City: Urban Policy Making in a Digital Age.” PS: Political Science \& Politics (this issue).

Brenner, Neil, and Christian Schmid. 2015. “Toward a New Epistemology of the Urban?” City 19 (2-3): 151-82.

Clarke, Susan E. 2017. "Local Place-Based Collaborative Governance: Comparing State-Centric and Society-Centered Models.” Urban Affairs Review 53 (3): 578-602.

Davies, Jonathan S., and David L. Imbroscio (eds.). 2009. Theories of Urban Politics. Thousand Oaks, CA: Sage Publications.

Donaghy, Maureen M. 2019. "Participation Meets Politics: Political Shifts and the Longevity of Participatory Governance Institutions.” PS: Political Science \& Politics (this issue).

Dreier, Peter, John Mollenkopf, and Todd Swanstrom. 2001. Place Matters: Metropolitics for the Twenty-First Century. Lawrence: University Press of Kansas.

Enright, Theresa. 2019. "Beyond Comparison in Urban Politics and Policy Analysis." PS: Political Science \& Politics (this issue). 
Enright, Theresa, and Ugo Rossi (eds.). 2017. The Urban Political: Ambivalent Spaces of Late Neoliberalism. Cham, Switzerland: Palgrave Macmillan.

Hinze, Annika M. S., and James M. Smith. 2019. "Comparative Approaches to Development Politics and the Quest for a More Robust Theory." PS: Political Science \& Politics (this issue).

Hooghe, Liesbet, and Gary Marks. 2003. "Unraveling the Central State, but How? Types of Multilevel Governance.” American Political Science Review 97 (2): 233-43.

Kaufmann, David. 2019. “Comparing Urban Citizenship, Sanctuary Cities, Local Bureaucratic Membership, and Regularizations." Public Administration Review 79 (3): 443-46.

Kohn, Margaret. 2016. The Death and Life of the Urban Commonwealth. Oxford: Oxford University Press.

Kübler, Daniel, and Michael A. Pagano. 2012. "Urban Politics as Multilevel Analysis.” In The Oxford Handbook of Urban Politics, ed. Karen Mossberger, Susan E. Clarke, and Peter John, 114-29. Oxford: Oxford University Press.

Landau, Loren. 2014. "Conviviality, Rights, and Conflict in Africa's Urban Estuaries.” Politics \& Society 42 (3): 359-80.

Lay, J. Celeste, and Anna Bauman. 2017. "Private Governance of Public Schools: Representation, Priorities, and Compliance in New Orleans Charter School Boards.” Urban Affairs Review 55 (4): 1006-34.

Magnusson, Warren. 2011. Politics of Urbanism: Seeing Like a City. Abingdon, Oxfordshire: Routledge.

Magnusson, Warren. 2014. "The Symbiosis of the Urban and the Political." International Journal of Urban and Regional Research 38 (5): 1561-75.

Michener, Jamila. 2018. Fragmented Democracy: Medicaid, Federalism, and Unequal Politics. 
Cambridge: Cambridge University Press.

Molotch, Harvey. 1976. "The City as a Growth Machine: Toward a Political Economy of Place." American Journal of Sociology 82 (2): 309-32.

Sapotichne, Joshua, and Bryan D. Jones. 2012. "Setting City Agendas: Power and Policy Change.” In The Oxford Handbook of Urban Politics, ed. Karen Mossberger, Susan E. Clarke, and Peter John, 442-67. Oxford: Oxford University Press.

Sbragia, Alberta M. 1996. Debt Wish: Entrepreneurial Cities, US Federalism, and Economic Development. Pittsburgh, PA: University of Pittsburgh Press.

Sidney, Mara. 2003. Unfair Housing: How National Policy Shapes Community Action. Lawrence: University of Kansas Press.

Sidney, Mara. Forthcoming. "Immigrant Identities and Integration in the United States and Canada.” In How Ideas Shape Urban Political Development, ed. Richardson Dilworth and Timothy P. R. Weaver. Philadelphia: University of Pennsylvania Press.

Simone, Abdou Maliq. 2004. "People as Infrastructure: Intersecting Fragments in Johannesburg." Public Culture 16 (3): 407-29.

Stone, Clarence. 1989. Regime Politics: Governing Atlanta, 1946-1988. Lawrence: University Press of Kansas.

Stone, Clarence. 2015. "Reflections on Regime Politics: From Governing Coalition to Urban Political Order." Urban Affairs Review 51 (1): 101-37.

Trounstine, Jessica. 2009. "All Politics Is Local: The Reemergence of the Study of City Politics." Perspectives on Politics 7 (3): 611-18.

Williamson, Abigail Fisher. 2018. Welcoming New Americans? Local Governments and Immigrant Incorporation. Chicago: University of Chicago Press.

Williamson, Abigail Fisher. 2019. "Intergovernmental Policy Feedbacks and Urban Responses to 
Immigrants.” PS: Political Science \& Politics (this issue).

Wong, Diane. 2019. "When Women Hold up the Sky: Shop Talk and Everyday Resistance to Gentrification in Manhattan's Chinatown.” New York University: Working paper. 


\section{SYMPOSIUM CONTRIBUTORS}

Raffaele Bazurli is a PhD candidate in political science and sociology at the Scuola Normale Superiore in Florence, Italy. He has held visiting-researcher positions at the Autonomous University of Barcelona and Sciences Po-Paris. His research focuses on migration policy, social movements, and urban affairs. He can be reached at raffaele.bazurli@sns.it.

Allison Bramwell is associate professor in political science at the University of North Carolina at Greensboro. Operating at the intersection of urban governance and political economy, her research examines the institutional dimension of economic transformation, technological innovation, and socioeconomic inclusion in restructuring regions. She can be reached at afbramwe@uncg.edu.

Maureen M. Donaghy is associate professor in political science at Rutgers University, Camden, New Jersey. Her research includes publications on urban development, participatory governance, civil society, and social welfare policy. She can be reached at Maureen.Donaghy@ rutgers.edu. Theresa Enright is assistant professor of political science at the University of Toronto. Her research is focused on urban and regional governance, critical urban theory, and the politics of transit. She is the author of The Making of Grand Paris: Metropolitan Urbanism in the TwentyFirst Century and editor (with Ugo Rossi) of The Urban Political: Ambivalent Spaces of Late Neoliberalism. She can be reached at theresa.enright@utoronto.ca.

Annika Marlen Hinze is associate professor of political science and director of the Urban Studies Program at Fordham University, Rose Hill. Her research and teaching focus on urban politics, the politics of immigration (in the United States, Germany, Canada, and the European Union), qualitative methods, urban economic development, poverty, and minority politics. Professor Hinze's first book, Turkish Berlin: Integration Policy and Urban Space (University of Minnesota Press, 2013), compares integration policy and lived integration of second-generation Turk- 
Germans in two Berlin neighborhoods. She can be reached at ahinze@fordham.edu.

David Kaufmann is assistant professor of Spatial Development and Urban Policy at ETH Zürich. He was a postdoctoral researcher at the KPM Center for Public Management, University of Bern during the development of this symposium. David Kaufmann is a public policy scholar with an interest in urban studies, spatial planning and migration studies. He can be reached at kadavid@ethz.ch.

Mara Sidney is associate professor of political science and co-director of the Global Urban Studies doctoral program at Rutgers University-Newark. Her publications and research focus on immigration, urban policy, and housing policy, with attention to the roles of nonprofit and advocacy organizations. She can be reached at msidney@newark.rutgers.edu.

James M. Smith is associate professor of political science at Indiana University South Bend. His research focuses on urban governance and institutions of urban development. He can be reached at jms21@iusb.edu

Abigail Fisher Williamson is a Charles A. Dana research associate professor of political science and public policy and law at Trinity College, Hartford, Connecticut. Her research interests include immigration and health policy, urban politics, and political behavior. She can be reached at Abigail.Williamson@trincoll.edu. 